\title{
THE SOLICITOR GENERAL AND THE INTERESTS OF THE UNITED STATES
}

\author{
DAVID A. STRA USS* \\ I \\ INTRODUCTION
}

The Solicitor General has authority to represent the U nited States before the Supreme Court in cases "in which the U nited States is interested." ${ }^{1} \mathrm{H}$ e also has broad power to supervise litigation conducted in the lower courts by lawyers representing the $U$ nited States, its agencies, and its officials. ${ }^{2}$ The Solicitor G eneral is often-and correctly - said to have special responsibilities to the Supreme Court, responsibilities different in kind from those of lawyers representing private clients. B ut the interesting and difficult questions about the Solicitor $\mathrm{G}$ eneral's role do not directly concern his responsibilities to the Supreme Court ("his" because no woman has yet been appointed Solicitor G eneral-a situation that will surely change soon). Rather, the difficult questions have to do with the Solicitor General's responsibilities as a member of the Executive $B$ ranch. To what extent is he, like most other high-ranking executive branch officials, properly concerned with carrying out the policies of the A dministration in which he serves? Or should he, instead, remain aloof from A dministration policies and concern himself only with the institutional interests of the federal government? A nd if the latter, how does one define the institutional interests of the federal government?

Q uestions like these have arisen with some regularity in recent years. D uring the R eagan and B ush A dministrations, for example, the President took the position that the Supreme Court's decisions establishing a right to have an abortion were wrong and should be overturned. When cases reached the Supreme Court in which state abortion laws were challenged, the Solicitor General participated as amicus curiae and urged that Roe v. Wade ${ }^{3}$ be overruled. ${ }^{4}$

Copyright $\odot 1998$ by L aw and Contemporary Problems

This essay is also available at http://www.law.duke.edu/journals/61L CPD Strauss.

* H arry N. Wyatt Professor of Law, U niversity of Chicago. The author was an A ssistant to the Solicitor G eneral from 1981 to 1985.

The L ee and Brena Freeman Faculty Fund and the Sonnenschein Fund at the U niversity of Chicago Law School provided support for this project.

1. 28 U .S.C. § 518(a) (1994).

2. See, e.g., 28 C.F.R. § 0.20 (1998).

3. 410 U .S. 113 (1973).

4. See, e.g., Brief for the U nited States as A micus Curiae in Support of the A ppellants, Thornburgh v. A merican College of Obstetricians \& Gynecologists, 476 U.S. 747 (1986) (N 0. 84-495). The episode is discussed in LinCOLn CA PLAN, THE TENTH JUSTICE: The SOLICITOR GENERAL AND the Rule of LAW 135-54 (1987); Charles Fried, ORder and LaW: ARguing the Reagan 
No federal programs were to be affected by these cases in any but the most indirect way; there were no federal laws forbidding abortion, for example. In that sense, the government's institutional interests were not affected. Was it nonetheless proper for the Solicitor G eneral to participate, in order to try to persuade the Supreme Court to adopt what the A dministration thought was the right view of the Constitution? Or should he have refrained from doing so, on the ground that his responsibility was not to the A dministration's views but to the government's institutional interests?

II

The Role of The SOlicitor General

These questions are the variant, for the Solicitor G eneral, of the familiar question for government lawyers: "W ho is the client?" ${ }^{5}$ There are, I think, two plausible approaches.

\section{A. The Institutional A pproach}

What I will call the institutional view says that the Solicitor General's responsibility is to the federal government as an institution, not to the President or the A dministration that he serves. The U nited States is a litigant that brings and defends suits in the courts, and its interest is in winning those suits. A ccordingly, there are certain things that lawyers in the D epartment of J ustice do, no matter who is A ttorney General or President. Government lawyers prosecute criminals. When the government is sued for damages, they defend the government. They often defend government officials who are sued in their personal capacity for damages, for torts or constitutional violations. When a statute, regulation, or government action is challenged as unconstitutional or otherwise unlawful, government lawyers defend what the government has done. They sue, or prosecute, violators of federal regulatory statutes.

This means that government lawyers will systematically find themselves on one side of certain issues. Not all issues: for example, the government can be both plaintiff and (at a different time) defendant in an employment discrimination action. But, if you want to represent criminal defendants, or tort plaintiffs, or if you want to devote your practice to expanding First or Fourth A mendment rights, or if you think congressional power under the Commerce Clause should be narrowed, then you will not find much of the kind of work you want in the J ustice D epartment.

A ccording to the institutional view of the Solicitor General's role, the Solicitor $\mathrm{G}$ eneral represents the same interests in the Supreme Court that other government lawyers represent in their day-to-day work. The Solicitor G eneral just happens to represent the government on high-visibility issues in the most

REV OLUTION 33-35 (1991); J oshua I. Schwartz, The President's L awyer as Frie(n)d, 60 GEO. W A SH . L. REV. 1081, 1119-24 (1992).

5. See, e.g, G eoffrey P. M iller, G overnment L awyers' E thics in a System of Checks and B alances, 54 U. CHI. L. REV. 1293 (1987). 
visible Court, and so comes under pressure to act differently from other government lawyers. B ut that is no reason for him to do so.

\section{B. The A dministration A pproach}

The other view of the Solicitor G eneral's role, which I will call the A dministration view, is that the Solicitor G eneral is just like any other high-ranking executive official: $H$ is task is to help carry out the A dministration's program. If the Administration's position is that the government should be allowed to forbid abortions, or that property owners should receive greater compensation for takings, or that the Supreme Court's standing cases are too restrictive, or that statements obtained in violation of M iranda v. A rizona ${ }^{6}$ should not be used even for impeachment, then the Solicitor General should try to advance those positions- even though each of them (abortions aside) will actually impair the government's ability to win its cases. This view emphasizes that the Constitution does not recognize the existence of an Executive B ranch distinct from the one that is directed by the President. The idea that the Solicitor General has a responsibility to a disembodied federal institutional interest that exists independently of a particular A dministration is, in all likelihood, just a way to enable career employees in the office, who may lack sympathy with the current A dministration's agenda, to pursue their own.?

The institutional and A dministration approaches would diverge not just on the abortion case but on other cases that are much less highly publicized but nonetheless quite important. Consider, for example, the following situation, again modeled on an actual matter that came before the Solicitor General's O ffice: A state government has asserted that sovereign immunity bars a claim for damages for an alleged taking of property without just compensation. The federal government faces similar claims and has in the past asserted a sovereign immunity defense. A loss by the state on the sovereign immunity issue will not necessarily foreclose the federal government's sovereign immunity defense, but it will be a serious blow to the ability of the federal government to assert such a defense. The President and other A dministration officials have taken the position, in various contexts, that government is in general insufficiently respectful of private property rights and should compensate property owners more often for actions that diminish the value of their property.

The A dministration view would at least entertain the possibility of filing a brief calling for the abrogation of the sovereign immunity defense, even though the result will be that the federal government will end up paying more money. The institutional view would insist on the opposite position: The role of the Solicitor $G$ eneral is to defend the interests of the government as a litigant. It is a misuse of his office to undermine a sound argument that the government might make.

6. 384 U .S. 436 (1969).

7. For a view like this one, see J ohn O. McGinnis, Principle Versus Politics: The Solicitor G eneral's O ffice in Constitutional and Bureaucratic Theory, 44 STA N. L. R E V . 799 (1992). 
This is not just a point about what might be thought of as the policies of a conservative A dministration. Here is another example, adapted from events that occurred in a Democratic A dministration: Private plaintiffs have sought an injunction against a federal policy. The federal government has a barely colorable argument on the merits but an excellent argument that, under existing law, the private plaintiffs' claim is not justiciable. (A ssume, to avoid other complications and to make it more likely that what the government says will matter, that the argument is not jurisdictional-for example, that the argument is that the plaintiffs do not satisfy one of the "prudential" elements of standing.) The A ttorney General has taken the position that Supreme Court doctrine on these questions of justiciability is too restrictive. Should the Solicitor General forgo any argument that is inconsistent with the A ttorney General's position, even if the effect is to turn a near-certain victory for the government into a near-certain defeat? A gain the institutional view, on these facts, is clear: The Solicitor $\mathrm{G}$ eneral's job is, at the least, to win cases for the government that can be won by making responsible arguments.

III

\section{The Solicitor General a sthe "Tenth Justice"}

The distinction between the institutional and $A$ dministration view of the role of the Solicitor $\mathrm{G}$ eneral might seem to leave out of the picture one of the most commonly held views: that the Solicitor $G$ eneral is not merely an official of the Executive Branch but someone who has special responsibilities to the Supreme Court-in some ways, a "tenth Justice." ${ }^{8}$ O ne version of this approach, at least, is easy to describe and understand. It holds that the Solicitor General should simply take the position that reflects his best judgment of what the law is, just as he would if he were literally a Justice. In the abortion case, under this approach, the R eagan and Bush Solicitors General acted properly if (and only if) they themselves agreed with the President's position on the constitutional issue.

The problem with this view is that the Solicitor $G$ eneral is a member of the Executive Branch, and it is not easy to see why a member of the Executive Branch should adopt this view of his job. Sometimes simply stating his impartial view of the best understanding of the law may happen to be the best way for the Solicitor General to help execute the laws. But surely sometimes the Solicitor $\mathrm{G}$ eneral will better help execute the laws if he acts as an advocate, seeking to advance a position that helps the government win what it is trying to win in court.

In any event, this tenth J ustice approach would, if implemented across the board, be foreign to the long-standing culture of the Solicitor $G$ eneral's O ffice. No recent Solicitor G eneral has adopted a policy of systematically refusing to take any position that he would not vote for as a J ustice. Indeed I suspect that

8. For a sustained statement of this view, see generally CA PLA N, supra note 4. 
every recent Solicitor G eneral could name many occasions on which he took a position before the Court that he would certainly have voted against if he were a J ustice. The $O$ ffice sees its principal business as advocacy-not advocacy of exactly the same kind that private lawyers do, but advocacy nonetheless. M ost documents that the Solicitor $G$ eneral files with the Court do not take an evenhanded view of an issue; they seek to advance the side that favors the government.

That is not to say that the Solicitor G eneral should act in the same way as a private lawyer. To this degree, there is something to the tenth J ustice idea. Solicitors General have uniformly believed that they should confess erroradmit that a lower court judgment in favor of the party they represent was mistaken and should be vacated-in circumstances in which a private party would not. (Private parties' confessions of error are essentially unheard of.) A nd, while confessions of error are not very common, it is not particularly unusual for the Solicitor $G$ eneral to refrain from making an argument in favor of his position-when a private lawyer would make a comparable argument-because he thinks the argument, although not frivolous, is simply too weak. Solicitors General have also consistently recognized an obligation to be more candid than private lawyers about authority that opposes their position and about awkward facts in the record.

Finally, in what is perhaps the closest approximation to the tenth Justice role, the Solicitor $\mathrm{G}$ eneral traditionally recognizes a responsibility to give relatively candid views to the Supreme Court about matters that affect the Court's own jurisdiction and prerogatives- relatively candid compared not just to what private parties would say, but to what the Solicitor General himself says when engaged in straightforward advocacy on an issue that does not directly affect the Court as an institution. Thus, the Solicitor General has traditionally been willing to admit that the Court might lack jurisdiction over an issue, or that a case does not satisfy the Court's usual criteria for granting certiorari, even when the government's litigating interests would be advanced by a contrary argument.

N otwithstanding all of this, I would venture that no one who has worked in the Solicitor $\mathrm{G}$ eneral's office, at least in recent times, has ever doubted that he was a lawyer representing a client, not an impartial judicial officer. The Solicitor $\mathrm{G}$ eneral is an advocate, and his principal day-to-day concern is promoting his client's interests. $\mathrm{H}$ is special responsibilities to the Court limit and qualify the pursuit of the client's interests, but advocacy on behalf of the client is the central task. The question is what such advocacy should consist of: whether it should resemble the institutional or A dministration view.

\section{IV}

The COSTSOF THE A dMINISTRATION A PPROACH

The difference between these two approaches is not just a peculiarity of the Solicitor $\mathrm{G}$ eneral's job. It reflects a genuine tension in the responsibilities that 
the Constitution assigns to the Executive B ranch, which is responsible for enforcing laws enacted by Congress. The tension arises because the President is not simply the faithful servant of Congress.

No one would deny, for example, that the President and the A ttorney G eneral may take positions on issues that do not yet effect the laws that the federal government enforces, such as when they propose legislation. B eyond that, the President or other Executive officials will take positions on issues that have essentially nothing to do with any laws that the federal government enforces. They might, for example, criticize (or praise) Supreme Court decisions on certain civil rights issues, abortion, or school prayer. From time to time, Presidents, in particular, take positions that might be inconsistent with the government's enforcement interests; they might call for an expansion of the ability of private plaintiffs to win damages from the government, or they might criticize the centralization of power in the federal government. No one would think that a President who took such a position was acting in a way that was inconsistent with the responsibilities of his office. The advocates of the A dministration view of the Solicitor G eneral's role say, in essence, that the Solicitor General should help the President in carrying out these political aspects of the Executive Branch's mission that go beyond simply executing the laws enacted by Congress.

The fact that the President can properly act in ways that might be at odds with the government's enforcement interests does not, however, mean that every executive branch official should feel free to do so. Members of the armed forces are of course employees within the Executive Branch, and they are (as the Constitution itself specifies) subordinates of the President. $Y$ et everyone would agree that in an important sense the military must not be used to carry out the President's political agenda. While the separation of the military from politics is perhaps uniquely important, a weaker version of the same point can be made about government law enforcement agents, and indeed about most government bureaucrats. In principle, of course, they are to carry out the Administration's policies; but day-to-day, they serve institutional interests, and there should be strict limits on the extent to which they carry out a political agenda.

$M y$ view is that while the A dministration approach to the Solicitor General's role is in a sense correct in principle, something like the institutional view should be followed in practice. It is of course true that the Solicitor $\mathrm{G}$ eneral is a member of the Executive Branch. In principle there is no reason to say that he can refuse to accept the policy choices and priorities of the President and the A ttorney General. More importantly, as I will discuss below, there does not seem to be any way to give a fully coherent account of the institutional interests of the $U$ nited States that does not refer to the policy priorities of the A dministration. On the other hand, the best allocation of responsibilities within the Executive B ranch would be for the Solicitor $G$ eneral to confine himself, mostly or entirely, to those things that the institutional approach endorses. That is the 
role that the Solicitor $G$ eneral should seek to play within the Executive Branch, and the President and A ttorney $G$ eneral should let him play that role.

Consider again the abortion case. It might be argued: Why should the Solicitor General not take a position in the Supreme Court just because the A dministration believes that the position is legally sound and believes that it is imperative, as a matter of policy or morality, to take that position? Why is it necessary to show that the position also somehow advances the government's institutional interest in enforcing the law?

A ccording to the logic of the institutional conception of the Solicitor G eneral's role, it might be argued, the Solicitor $G$ eneral should not have supported the parties challenging segregation in B rown v. B oard of E ducation ${ }^{9}$ and other cases from the 1940s and 1950s. A that time, the government had only a limited role in civil rights enforcement, and there was little federal institutional interest in a ruling against segregation. The Solicitor $G$ eneral's participation in those cases apparently was the result of a moral commitment and a political calculation. ${ }^{10}$ The reapportionment cases-in which Solicitor General A rchibald Cox urged the Court to reconsider precedents that permitted malapportioned legislatures-are another example. ${ }^{11}$

No one could say that the President would act improperly if he sought to lend the moral authority of his office to, for example, the plaintiffs in Brown v. Board of E ducation. Q uite the contrary: President E isenhower's lukewarm response to the decision was seen by many as an abdication of his moral responsibilities. If the President could properly have supported the plaintiffs in Brown in his speeches-indeed, perhaps even morally ought to have supported them-why must the Solicitor General be barred from trying to implement what the President sees as a moral imperative, by making arguments to the Supreme Court that might persuade the Court to reach the result that the President supports? And, if this is true in B rown and the reapportionment cases, then as an institutional matter-one can of course disagree on the merits-it ought to be true in the abortion case as well.

On the other hand, there are costs when the Solicitor G eneral participates in such a case. Those costs become clearer if one focuses not on a once-in-ageneration case, like Brown or the abortion cases, but on whether the Solicitor General should be able to subordinate federal institutional interests to the A dministration's policy choices in less momentous cases, like sovereign immunity or standing cases. The costs derive from two sources.

9. 347 U .S. 483 (1954).

10. A t least according to the somewhat controversial account given by Philip E Iman, The Solicitor General's Office, Justice Frankfurter, and Civil Rights Litigation, 1946-1960: An O ral History, 100 HARV. L. REV . 817, 818-19 (1987).

11. There is an argument that the federal government has an institutional role in these cases-the Constitutional provision that "[t]he U nited States shall guarantee to every State... a Republican Form of G overnment" was one of the bases on which the cases could have been decided-but that was not the reason that the Solicitor G eneral participated. See U .S. CONST. art IV , § 4. 
The first is the relationship of the Solicitor G eneral's O ffice to the Court. This is a more limited version of the often overstated "tenth J ustice" idea. The Solicitor $\mathrm{G}$ eneral's O ffice appears before the Supreme Court dozens of times a year. ${ }^{12}$ The $O$ ffice's reputation with the J ustices, and the Court's image of the Office, are very important both to the O ffice's ability to do its job for the EXecutive Branch and to the functioning of the government in general. ${ }^{13}$ If the Court generally trusts the $O$ ffice to engage in its traditional form of advocacywhich, as noted above, falls somewhere between what a private party would do and the impartial "tenth J ustice" version - the 0 ffice will be more effective.

M oreover, the Court's work can be greatly enhanced if the Court is able to trust the $O$ ffice in certain ways, because the $O$ ffice can potentially be very valuable to the Court. The $O$ ffice provides responsible and high-quality advocacy, of course, but the Office is also one of the Court's few sources of information about the effects of legal rules and decisions in the world. The Court is constantly making judgments about those effects: Is a particular lower court decision important enough to warrant review? Will a particular interpretation of the F ourth A mendment really hamper law enforcement? Will an interpretation of the Freedom of Information A ct affect the ability to gather intelligence? Much of the information the Court needs to make these determinations comes from the Solicitor General, and it is difficult to see from where else the Court could possibly get such information. Moreover, the Court is necessarily in the position of receiving not just factual information but also judgments from the Solicitor $\mathrm{G}$ eneral. If the Court can trust the Solicitor $\mathrm{G}$ eneral to provide accurate information and reliable judgments, the Court's ability to do its job is improved.

The Solicitor G eneral is engaged in advocacy, not impartial commentary or advice, and the Court knows that. B ut the Court has a significant community of interests with the institutional agenda of the federal government, including the Solicitor G eneral's O ffice. The Court does not want to see the government unable to perform its legitimate functions. R eceiving a responsible account of what the government thinks it needs to discharge those functions-an advocate's account, but one intended to illuminate the government's view of what it needs-is a great asset to the Court. When what the Court receives from the Solicitor General is instead an argument, or a judgment, that is motivated by political concerns-even political concerns of the highest moral order-the Court is no longer getting the kind of material it most needs, and the community of interest between the $\mathrm{O}$ ffice and the Court is eroded.

12. Strictly speaking, the Solicitor G eneral appears in hundreds of cases each Term, since he is the respondent to many certiorari petitions. In most of those instances, however, there is no serious question about the outcome. The cases in which the outcome is in doubt (including both certiorari petitions and cases on the merits) numbers in the dozens.

13. For a development of these themes, see Neal D evins, Tempest in an E nvelope: R eflections on the Bush White House's Failed Takeover of the U.S. Postal Service, 41 U CLA L. REV. 1035, 1040-41 (1994); N eal D evins, U nitariness and Independence, 82 C A L. L. R EV . 255 (1994). 
In addition, as long as the 0 ffice engages in forms of advocacy that are familiar to the Court-defending the institutional interests of the government, without regard to the political agenda of the Administration in power-the Court has a good sense of the limits and value of the advocacy it is receiving. Familiarity, in this context, is a signal virtue. The 0 ffice will function best, both in the achievement of its own objectives and in helping the Court do its job, when it seems to the Court that it is seeing the same, familiar Solicitor G eneral's O ffice in every case- preferably, the same Solicitor G eneral's O ffice that it saw when the other political party was in power. The Court can discount for the Office's professional biases and proceed accordingly. The Court also knows that, to the extent the $O$ ffice is concerned with the government's institutional interests, rather than the A dministration's political interests, the O ffice has a stake in maintaining a long-term relationship with the Court and will act accordingly. The $\mathrm{O}$ ffice will not risk its credibility for the sake of victory in a single case.

When part of the work of the Office responds to a particular A dministration's political agenda, the relationship between the $O$ ffice and the Court can come unsettled. M any issues that come before the Court are not high profile political controversies like abortion but are nonetheless potential opportunities for the Administration to score political points: areas like criminal law, civil rights, environmental protection, antitrust, labor law, and tax enforcement, for example. If the Solicitor $\mathrm{G}$ eneral's $\mathrm{O}$ ffice sometimes takes positions because it is promoting the A dministration's agenda, the Court is then entitled to wonder, in each of these areas, whether it is hearing from the institutional Officewhich is concerned primarily with maintaining its relationship with the Court, and with whose biases and predilections the Court is familiar-or the political O ffice, which may be addressing not the Court but a very different audience, and for whose tendencies and biases the Court will not have as good a feel.

M ore importantly, lawyers concerned with promoting a single A dministration's political agenda do not have the same incentives to maintain their longterm credibility with the Court. Once the Solicitor General and his staff are free to go beyond the institutional interests of the government, and to advocate a political agenda, they will naturally ask themselves: Why should we husband our credibility for institutional issues we care about less- or, worse still, for a subsequent Administration-instead of spending it on our own political agenda? The point is not that adherents to the $A$ dministration view will engage in misleading or other improper advocacy. It is that, given the ongoing relationship between the Solicitor General and the Court, the Solicitor General must be selective in almost everything he does: seeking certiorari, stays, or summary reversals; using strong rhetoric (for example, arguing that a case seriously impairs the government's ability to enforce the criminal laws); and so on. If the Office's time horizon is four years, and if the Solicitor General sees his agenda as the pursuit of a small number of politically salient causes, then he will have an entirely different attitude toward this task, and the 0 ffice's ability to perform its institutional role will be weakened. 
The second set of costs that the A dministration approach incurs have to do with the internal culture of the Solicitor $\mathrm{G}$ eneral's $\mathrm{O}$ ffice. Traditionally the $\mathrm{O} f$ fice has not been seen as a place where a lawyer goes to pursue a political agenda. On the contrary, people can work together for years in the Office without a clear sense of each other's political views. A $n$ institutional ethos of that kind acculturates lawyers to thinking of their task as the pursuit not of political objectives but of the government's institutional interests. M any lawyers also join the 0 ffice relatively early in their careers, at a point where their view of the job can be shaped by the existing culture in the 0 ffice. To the extent the O ffice comes to see itself as serving a political role, the lawyers in the office will increasingly think of themselves in those terms. The 0 ffice will become less attractive to people who do not share the politics of the incumbent A dministration.

This, too, would be a cost. It is likely to lower the average quality of lawyers in the office, because people of the opposing political persuasion will be less interested in working there. It will undoubtedly impair the O ffice's effectiveness with the Court-across the full range of cases-if the 0 ffice takes on a partisan cast. It will also be a difficult trend to reverse: O nce partisans of one side have used the Office's credibility and reputation for their cause, it will be hard to persuade the other side, when it succeeds to power, not to do the same.

\section{$\mathrm{V}$}

\section{THE LIMITS OF THE INSTITUTIONA L A PPROACH}

A II of this seems to suggest that the Solicitor G eneral should concern himself with the institutional responsibilities of the federal government and should not promote a particular A dministration's political agenda. But matters are a little more complicated than that, in several respects.

First, an occasional political act by the Solicitor General's O ffice may not always have the costs I described. A Solicitor G eneral could plausibly say that, so long as he adheres to the institutional view in every other case, he will not harm the $O$ ffice significantly by taking a position, in a case in which the government has no institutional interest, on a once-in-a-generation issue like abortion or school desegregation. The Court will recognize such a case as exceptional and will not think the Office has become politicized; lawyers in the O ffice who are uncomfortable with that position will have many other cases to work on. In this way, the cases that are likely to damage the 0 ffice's reputation are, perhaps surprisingly, the less prominent ones-like the sovereign immunity example given above. It is the pursuit of an A dministration agenda in the relatively routine cases that will produce the most troublesome consequences. That is what undermines the Court's confidence in the $O$ ffice, as well as the $O f$ fice's own internal culture.

The Reagan and Bush Administration's advocacy in the abortion cases might seem to be a counterexample; their calls for overturning Roe v. Wade were widely seen to have politicized the Office. When the Court refused to 
overturn Roe, its opinion seemed to suggest that the A dministration's efforts had had the opposite effect. ${ }^{14}$ of course, at least until the Justices' papers become available, any conclusions about what actually swayed them will have to be speculative. It may be that even in the once-in-a-generation case, the Solicitor $G$ eneral can step outside the institutional role only if the A dministration's position does not touch a matter of intense political controversy (as in the reapportionment case) or when the legal culture is not deeply divided and the dominant opinion is sympathetic to the A dministration's position (as, perhaps, in the school segregation cases).

There is another, more fundamental reason that the A dministration conception of the Solicitor General's responsibilities cannot be rejected outright. The line between the institutional interests of the government and the political agenda of a particular A dministration is difficult to define. Indeed, it is not always easy even to identify the institutional interests of the federal government in the abstract, unconnected to a set of specific policies. If an A dministration has decided that, as a matter of policy, the enforcement of the drug laws is especially important, the Solicitor G eneral will naturally place a priority (in deciding when to seek certiorari or to participate as an amicus, for example) on expanding the government's power to conduct searches. E ven the most rigorous proponent of the institutional view would admit that the Solicitor General may properly do that. The same would be true if the $A$ dministration placed a priority on environmental protection or antitrust or civil rights enforcement; no one could reasonably expect the Solicitor $G$ eneral to ignore those priorities in allocating his O ffice's resources (time and energy; credibility with the Court). By the same token, if an A dministration decided that the federal government was exercising too many powers that should be left to the states, it would only make sense for the Solicitor $\mathrm{G}$ eneral, even under the institutional view, to softpedal efforts to expand federal authority at the expense of the states, and instead to invest the 0 ffice's resources elsewhere.

A nother example that arose in essentially this form in the Reagan A dministration shows especially clearly that the government's institutional agenda is not analytically distinct from the A dministration's policy agenda. Suppose the A dministration has proposed legislation that would provide aid to religious schools. While the legislation is pending-with uncertain prospects of enactment-a case reaches the Supreme Court in which indistinguishable state legislation is challenged on constitutional grounds. If that challenge succeeds, the A dministration's proposed legislation would be unconstitutional. A gain the line between the institutional view and the $A$ dministration view blurs. There is as yet no federal program that can be affected by the outcome of the case. If the Solicitor General participates in the case, he may seem to be acting as a mouthpiece for the A dministration's political agenda rather than as a representative of the government's institutional interests. But it seems odd to say, even under the institutional approach, that the Solicitor $\mathrm{G}$ eneral can do nothing in a

14. See Planned Parenthood v. Casey, 505 U .S. 833, 867, 868 (1992). 
Supreme Court case that may doom what might otherwise be important federal legislation.

A final and related point is that not all aspects of an Administration's agenda will be equally threatening to the Solicitor $G$ eneral's relationship to the Court and to the nonpolitical culture of the Office. Some agenda items may seem highly "political" in a bad sense; others, while not promoting recognizable institutional interests, will not. The religion example just given, to the extent it is troubling, is troubling because the Court and other observers may believe that the $O$ ffice is taking a position just because it is trying to score political points and not because it actually has something to say to the Court. ${ }^{15}$ Conversely, in the reapportionment cases, it seems unlikely that the Court would have had this concern; that makes the Solicitor General's participation less problematic. In an A dministration that had not made public support for religion a central aspect of its political agenda, the Solicitor G eneral's relationship to the Court (and the internal culture of the Solicitor General's office) might not be adversely affected by the Solicitor $G$ eneral's decision to take positions that arguably went beyond the government's institutional interests. In an Administration that tried to gain political advantage by emphasizing its commitment to enforcement of the criminal laws, even the pursuit of undeniable institutional interests-if the pursuit were perceived as being too vigorous-might harm the O ffice's credibility with the Court.

\section{VI}

\section{CONCLUSION}

No simple formula can capture the complex nature of the Solicitor G eneral's responsibilities. The conventional wisdom of career lawyers in the Solicitor $\mathrm{G}$ eneral's $\mathrm{O}$ ffice is that the Office serves the institutional interests of the $U$ nited States. B ut the government's institutional interests cannot be identified in isolation from a particular A dministration's policy priorities. In addition, it is difficult to explain why the Solicitor G eneral cannot occasionally take a position in the Supreme Court solely to vindicate an A dministration's vision of the Constitution; the costs of the Solicitor General's doing so are unlikely to outweigh the benefits on every occasion.

On the other hand, there are substantial costs when the Solicitor G eneral departs from the institutional conception of his role. It is no answer to incant that the Solicitor $G$ eneral is a member of the Executive Branch and therefore subordinate to the President. The President, and the responsibilities of the $E x-$ ecutive Branch, can be served in many ways. By and large- not in every

15. J ustice Powell's concurring opinion in A guilar v. Felton, 473 U .S. 402, 416-17 (1985), referred to the danger that such certain forms of public aid to religious schools would produce unhealthy political division along religious lines-a discussion that has been read by some as suggesting that he was reacting against what he perceived as the R eagan A dministration's treatment of this issue. A guilar was overruled by A gostini v. Felton, 117 S. Ct. 1997 (1997). 
imaginable circumstance, but by and large-the Solicitor General's Office serves them best by pursuing an institutional mission. 